$\checkmark$ Research Square

\title{
Molecular Detection and Characterization of Pasteurella multocida Infecting Camels in Marsabit and Turkana Counties, Kenya
}

Justus Kyalo Kasivalu

Kenyatta University

George Isanda Omwenga ( $\square$ omwenga.george@ku.ac.ke)

Kenyatta University

Gabriel Oluga Aboge

University of Nairobi

\section{Research Article}

Keywords: Pasteurella multocida, Retrospective, Conventional PCR, Multiplex PCR, KMT1 gene, Kenya, Capsular

Posted Date: October 13th, 2021

DOI: https://doi.org/10.21203/rs.3.rs-923714/v1

License: (c) (i) This work is licensed under a Creative Commons Attribution 4.0 International License. Read Full License 


\section{Abstract}

\section{Background}

Infection with Pasteurella multocida is abundant in Kenya yet there is scarce information on their genetic diversity. Pasteurella multocida is considered to be one of the normal flora in the respiratory tract of camels and other animals but it becomes pathogenic and causes pasteurellosis when the resistance of the camel body is diminished by harmful environmental influences. Close herding, overwork, limited food supply, and wet climatic conditions are stresses that seem to speed the spread of the infection. Conventional PCR, Multiplex PCR and sequencing were applied to enhance identification of Pasteurella multocida at any level of specificity viz; strain, species, and genus. These molecular tools were applied to confirm the presence and genetic diversity of Pasteurella multocida in 102 blood and 30 nasal swab samples collected from Marsabit and Turkana counties in Kenya. Kmt1 gene was used as the marker gene for Pasteurella multocida and hyaD-hyaC, $b c b D, d c b F, e c b J$, and $f c b D$ as marker genes for capsular groups. A study done in northern Kenya noted that in Africa pasteurellosis infections causing death in camels (Camelus dromedarius) have been existing since 1890 though the real cause of this disease remains elusive and needs further study. The study was done to detect Pasteurella multocida and characterize its capsular types by application of molecular biology tools

\section{Results}

Twenty one Kenyan isolates were confirmed to be Pasteurella multocida and only capsular group E was detected in both counties. Pasteurella multocida sequences were found to be highly conserved, however isolates detected in Kenya were found to be genetically related to other isolates from African and other parts of the world.

\section{Conclusions}

The study confirm that the camels were infected by Pasteurella multocida of capsular type E in Marsabit and Turkana Counties of Kenya. DNA sequences were found to be homologous to Pasteurella multocida thereby confirming that the camels were infected by Pasteurella multocida.

\section{Background}

Pasteurellosis caused by Pasteurella multocida is an important disease that infect the respiratory tract of camels. Pasteurellosis in Kenya and worldwide causes economic losses linked to fatalities, drop in productivity and enormous cost on vaccination and medication $[11,22]$. P. multocida causes pasteurellosis when the resistance of the camel body is diminished by harmful environmental influences such as sudden changes in weather, deficiencies of dietary nutrition, long distances transportation and parasitic infestation [11]. Susceptibility to infection is thought to be increased by closely herding animals while wet conditions enhance the fast spreading of the disease $[6,26,30]$. Pasteurellosis has low morbidity but mortality rates may be $80 \%$ or higher. Carrier or sick camels are considered as source of 
infection to other animals especially young calves by direct contact, on fomites, through ingesting or breathing in of the $P$. multocida which probably comes from the nasopharynx of infected animals $[2,6$, $11,26]$. Where there is confirmation of pasteurellosis as a secondary complication, mortality may approach $100 \%$ if interventions are not applied at the beginning of the infection $[6,26]$.

Pasteurellosis is prevalent in Kenya and globally. A study done in northern Kenya report that in Africa pasteurellosis causing death in camels have been in existence since 1890 though the real cause of this disease remains elusive and needs further study [14]. Pasteurellosis is widely distributed with most occurrence in south East Asia, Middle East and some countries in southern Europe as well as in Japan and North America. Camel's pasteurellosis in Africa occurs sporadically, limited in extent and mostly associated with stress conditions $[12,27]$. P. multocida is a heterogenic organism due to varied antigenic specificity. Based on capsular composition, P. multocida strains are classified into five capsular groups A, $B, D, E, F[4,5,28,31]$. The organism express polysaccharide capsule on their surface based on capsule antigen. The capsule contain unique genes which encode proteins that take part in the synthesis of group specific capsular polysaccharides [31]. Capsular group A hyaD gene synthesis hyaluronic acid, capsular group $\mathrm{F} f c b D$ gene encode chondroitin, capsular group $\mathrm{D} d c b F$ gene take part in synthesis of heparin, capsular group $\mathrm{B}$ and $\mathrm{E} b c b D$ and $e c b J$ gene respectively encode glycosyltransferase [4].

Pasteurellosis determination is difficult because of multiple clinical presentations and tedious laboratory protocols, furthermore the clinical presentations of camel pasteurellosis can be confused with Middle East respiratory syndrome coronavirus (MERS-CoV) thus there is need to differentiate pasteurellosis from MERS-CoV infection. Detection and molecular characterization of $P$. multocida has relied greatly on application of biochemical, molecular assays and other methods. Identification of $P$. multocida has been observed to be greatly enhanced by the use of the PCR technique [1]. Molecular characterization and understanding the genetic diversity of $P$. multocida is important for diagnosis, study of disease epidemiology, development of vaccine and detection of mutations of strain circulating in a region [3]. This study was carried out to detect $P$. multocida and characterize its capsular types in Marsabit and Turkana counties in Kenya.

\section{Methods}

\section{Study area and study design}

Eight locations in two separate counties were investigated for $p$. multocida infections, five locations in Marsabit County and three locations in Turkana County. Marsabit County $\left(37^{\circ} 58^{\prime} \mathrm{E}, 2^{\circ} 19^{\prime} \mathrm{N}\right)$ is situated in northern Kenya bordering Wajir County to the east, Ethiopia to the north, Isiolo County to the south east. Its size is $70,961 \mathrm{~km} 2$ and a population of about 459,785 . Marsabit camel population is approximately 132,215 . Turkana County $\left(3^{\circ} 09^{\prime} \mathrm{N} 35^{\circ} 21^{\prime} \mathrm{E}\right)$ is located in northern Kenya bordering Samburu to the South-east, Marsabit to the East, Baringo and West Pokot to the South-west, Uganda to the west, and South Sudan to the north and Ethiopia to the north-east. It covers $68,680 \mathrm{~km} 2$ with a population of about 
926,976 . Turkana camel population is approximately 456,826 [7]. The study was a retrospective study that used samples collected for diagnostic purpose.

\section{Sample collection}

A total of 132 samples $(n=132)$ were collected, 61 EDTA blood in November 2018 at five locations viz Laisamis-moile, Nairibu, Malabot, El burumagado and Galas in Marsabit County, 41 EDTA blood and 30 nasal swabs in April 2019 at three location viz Nadapal, Lokolia and Lokore in Turkana County from randomly selected clinically sick camels population that had been affected by pasteurellosis like disease. A P. multocida Kabete isolate was used as a positive control and nuclease free water as a negative control. The authority to use the EDTA whole blood and nasal swabs archived at Central Veterinary Laboratories Kabete was sought from State Department of Livestock, Directorate of Veterinary Services in Kenya (Figure 8).

\section{DNA extraction}

The frozen whole blood samples and swabs where retrieved from freezer and left to thaw at room temperature. The genomic DNA was extracted using Invitrogen PureLink Genomic DNA mini Kit Cat. No.k1820-01 for purification of genomic DNA by thermofisher Scientific. Water bath was pre-set at $55^{\circ} \mathrm{C}$. To a sterile Microcentrifuge tube $200 \mu \mathrm{L}$ of frozen whole blood and nasal swab suspension was added then $20 \mu \mathrm{L}$ of each proteinase $\mathrm{K}$ and RNase A were added, mixed by briefly vortexing and incubated for 2 minutes at room temperature. Homogenous solution was made by vortexing after adding $200 \mu \mathrm{L}$ of lysis/ binding buffer. The homogenous solution was incubated at $55^{\circ} \mathrm{C}$ for 10 minutes to promote protein digestion. DNA was precipitated using $96 \%$ ethanol and bound to a resin on a mini spin column, the column was centrifuged at $12000 \mathrm{rpm}$ for 1 minute at room temperature. The flow through was discarded together with the collection tube. The spin column was placed into a new collection tube. The column was washed twice by adding $500 \mu \mathrm{L}$ wash buffers 1 and 2 and centrifuged at room temperature at 12000 rpm for 1 minute and maximum speed for 3 minutes respectively to remove the lysis buffer. DNA was eluted using elution buffer [17]. The DNA was kept at $-20^{\circ} \mathrm{C}$ awaiting PCR analysis.

\section{Detection of $p$. multocida by conventional PCR and multiplex PCR}

Conventional PCR amplification targeting 460bp KMT1 gene fragment using specific primers previously designed by Townsend et al., (1998) (Table 5) was used to detect $P$. multocida. The component for DNA amplification master mix for $P$. multocida in a total volume of $18.0 \mu \mathrm{l}$ were nuclease free water $12.2 \mu \mathrm{l}, 5 \mathrm{x}$ PCR buffer $2.5 \mu \mathrm{l}, 10 \mathrm{mM}$ dNTPs $0.5 \mu \mathrm{l}, 10 \mu \mathrm{M}$ forward primer $0.5 \mu \mathrm{l}, 10 \mu \mathrm{M}$ reverse primer $0.5 \mu \mathrm{l}, 3 \mathrm{mM} \mathrm{MgCl} \otimes$ $1.5 \mu \mathrm{l}$ and Taq DNA polymerase 3unit, $0.3 \mu \mathrm{l}$. The amplification conditions were initial denaturation at $94^{\circ} \mathrm{C}$ for $3 \mathrm{~min}$ followed by 30 cycles of denaturation at $94^{\circ} \mathrm{C}$ for $45 \mathrm{sec}$, annealing at $55^{\circ} \mathrm{C}$ for $45 \mathrm{sec}$, extension at $72^{\circ} \mathrm{C}$ for $45 \mathrm{sec}$, final extension at $72^{\circ} \mathrm{C}$ for $6 \mathrm{~min}$, holding at $10^{\circ} \mathrm{C}$ until removal. $5 \mu \mathrm{l}$ of PCR products was mixed with loading dye and analysed by gel electrophoresis on a $1.5 \%$ agarose gel. Multiplex PCR was applied for capsular type to differentiate $P$. multocida based on the genetic organization of the lipopolysaccharide [28].The capsular specific primers are designed for detection of 
capsular gene sequences, characterization and analysis of capsular groups [11]. All P. multocida KMT1 gene confirmed positives were subjected to multiplex PCR using specific Primers previously designed by Townsend et al. (2001) for capsular group's determination (Table 5). DNA amplification was carried out with a reaction volume of $20.0 \mu \mathrm{l}$ containing nuclease free water $4.0 \mu \mathrm{l}, 5 \mathrm{x}$ PCR buffer $10.0 \mu \mathrm{l}, 10 \mathrm{mM}$ dNTPs $1.25 \mu \mathrm{l}, 10 \mu \mathrm{M}$ primer pair each $1.25 \mu \mathrm{l}, 3 \mathrm{mM} \mathrm{MgCl} \otimes 1.5 \mu \mathrm{l}$, Taq DNA polymerase 3unit $0.75 \mu \mathrm{l}$. Amplification conditions were initial denaturation at $95^{\circ} \mathrm{C}$ for $5 \mathrm{~min}$ followed by 30 cycles of denaturation at $95^{\circ} \mathrm{C}$ for $1 \mathrm{~min}$, annealing at $55^{\circ} \mathrm{C}$ for $1 \mathrm{~min}$, extension at $72^{\circ} \mathrm{C}$ for $1 \mathrm{~min}$, final extension at $72^{\circ} \mathrm{C}$ for $7 \mathrm{~min}$, holding at $10^{\circ} \mathrm{C}$ until removal. $5 \mu$ of PCR products was mixed with loading dye and analysed by gel electrophoresis on a $1.5 \%$ agarose gel.

\section{DNA sequencing of pasteurella multocida}

Twenty one (21) PCR products of the isolates amplified using oligonucleotides targeting KMT1 and hyaD$h y a C, b c b D, d c b F, e c b J$, and $f c b D$ capsular genes were sequenced, some at International Atomic Energy Agency (IAEA) Seibersdorf Laboratories, Vienna, Austria and others at inqaba biotec Africa's genomic company, South Africa using Sanger dideoxy sequencing procedure [24].

\section{Sequence alignment, blast analysis and phylogenetic analysis}

BLASTn tool of the NCBI GenBank database was used to analyse the sequenced DNAs. The correct species identification was arrived at by comparing the query nucleotides sequences with GenBank database available sequences. The closest BLASTn match was used to confirm the species identification to the homologous sequences found in the GenBank database. The sequences were viewed using chromas version 2.6.6 [34] and assembled using Geneious prime program version 2020.2.4 [25] to allow for editing of the assembly and creation of consensus sequence. BioEdit software $[15,16]$ was used to import, align sequences, save aligned sequences and BLAST on NCBI (National Centre for Biotechnology Information) for sequence similarity. MEGA X [23] was used to construct phylogenetic tree by Maximum Likelihood method to determine relatedness. The internal branches statistical significance was inferred by bootstrapping with 1000 interactions.

\section{Results}

\section{Pasteurella multocida detected by PCR}

Molecular detection of $P$. multocida was arrived at by amplifying the targeted $K M T 1$ gene a transmembrane protein of $460 \mathrm{bp}$ size (Panel A figure 1). The total number of samples in Marsabit were sixty one (61), fifteen (15) were positive and Turkana had seventy one (71), six (6) were positive. A total of $16 \%(21 / 132)$ samples for the two counties showed amplification product with KMT1 primers. Marsabit County showed the highest prevalence of $P$. multocida detection with $11.4 \%(15 / 132)$ and Turkana with the lowest prevalence of $4.6 \%$ (6/132). Marsabit County, Malabot Location had the highest prevalence of $25 \%$ (4/16) and Laisamis-Moile had the lowest prevalence of $20 \%(2 / 10)$. Turkana County, Nadapal Location had the highest prevalence of $27 \%(3 / 11)$ and Lokore Location had the lowest prevalence of $3 \%$ 
(1/30). Based on the sample type the highest prevalence of $P$. multocida detection was recorded in EDTA blood with $14.4 \%(19 / 132)$ and $1.52 \%(2 / 132)$ for nasal swabs.

P. multocida capsular typing was done by Multiplex PCR with capsule-specific primers pairs for capA gene hyaD-hyaC, capB gene $b c b D$, capD gene $d c b F$, capE gene ecbJ, and capF gene $f c b D$ designed by Townsend et al. (2001). Among twenty one (21) DNA identified as $P$. multocida, capsular type E was the only capsular polysaccharide detected by Multiplex PCR in twenty (20) P. multocida positive samples. A distinct amplicon of $511 \mathrm{bp}$ size denoted the presence of capsular type $\mathrm{E}$ for $e c b J$ gene (Panel $\mathrm{B}$ figure 1). Other capsular types where not detected. Additional blot images shows this in more details (see additional file 1)

\section{Pasteurella multocida confirmed by sequencing}

PCR products for 21 p. multocida positive samples were sequenced. All samples generated nucleotide sequences viable for further analysis. Sequence analysis by BLASTn tool for the 21 sequences had a $99 \%$ to $100 \%$ nucleotide similarity to GenBank nucleotide. The isolates had homologues that were identical to Pasteurella multocida revealing that the camels in Marsabit and Turkana counties were infected. The 21 PCR product for capsular types were sequenced to confirm whether they are of capsular type $\mathrm{E} e c b \mathrm{~J}$ gene. Twenty samples produced quality sequences ready for further analysis while one sample did not produce quality results. BLASTn analysis revealed homologues that were identical to $P$. multocida capsule biosynthesis gene. The homologues identities and $E$ values are shown in Table 2 and 3 . The sequences obtained are found in additional file (see additional file 2)

\section{Results of nucleotide sequence alignment}

\section{Multiple sequence alignment of $P$. multocida isolates with others from other regions}

Multiple sequence alignment of $P$.multocida sequences indicate that most sequences were highly conserved except for Kenyan isolates identities [mar/gal/c24] [tur/nad/c1] [tur/lok/c14]. $P$ .multocida Sequences from Egypt and Russia were similar to Kenyan isolates. Isolates sequences from Ethiopia, USA, India, China, Denmark, Japan and Germany were different from Kenyan isolates (Table 4)

\section{Phylogenetic analysis}

Phylogenetic tree was constructed by maximum likelihood method to deduce whether the $P$. multocida is genetically diverse in different regions of the world. The aligned sequences were run on MEGA $X$ version 10.1 [23] to deduce the relatedness of Kenya P. multocida to isolates from Ethiopia, USA, India, China, Denmark, Egypt, Russia, Japan and Germany. Egypt and Russian isolate clustered in clade I with five (5) Kenyan isolates. Two (2) Kenyan isolates clustered in clade II and III respectively forming outgroup to clade I. The China isolate clustered in clade IV with one (1) Kenyan isolate indicating that they have a common ancestor. The positive control isolate clustered in clade $V$ with four (4) Kenyan isolates. Three Kenyan isolates from Marsabit clustered together in clade VI. The Indian, Japan and Germany isolates clustered in clade VII with three (3) Kenyan isolates. The USA and Ethiopian isolate clustered in clade VIII 
while Denmark and Indian isolates clustered in clade IX with two (2) Kenyan isolates (Figure 2). The results of the phylogenetic analysis indicate that the Kenyan $P$. multocida strain is diverse.

\section{Discussion}

A number of fungi, bacteria, viruses, and parasites may possibly cause respiratory infection in camels, but the definitive etiology has not yet been determined [30]. P. multocida cause acute septicemic disease attributed to high morbidity and mortality in sheep, goat, cattle, poultry and eventual economic losses [11, 26]. A capsulated strain of $P$. multocida can be organized into one of the groups $A, B, D, E$ and $F$ based on distinct capsular polysaccharides $[4,5]$. The hyaD gene is distinct for capsular group A strain purposely for the synthesis of hyaluronic acid, $f c b D$ gene specific for capsular group $\mathrm{F}$ encode chondroitin, $d c b F$ gene take part in synthesis of heparin in capsular group $\mathrm{D}$, gene $b c b D$ and $e c b J$ encode glycosyltransferase specific for capsular group B and E [31]. This study was done to investigate the active blood and nasopharyngeal carrier state for $P$. multocida in camels in Marsabit and Turkana counties in Kenya. The study applied PCR assay build on primers pair targeting KMT1 gene a transmembrane protein mostly used for initial $P$. multocida species identification of field strains regardless of capsular group [32]. The amplification of positive control and isolates was very specific to $P$. multocida species. The primer pair targeting KMT1 gene was employed to overcome tediousness and disadvantage of conventional methods used for detection of $P$. multocida and to rapidly confirm the results [32]. The PCR assay certified the specificity and sensitivity with desired results. PCR assay slightly modified from Townsend et al. (1998) was successfully optimized to detect $P$. multocida and its capsular types circulating in Marsabit and Turkana counties. PCR products run on agarose gel produced a distinct 460bp size corresponding to $P$. multocida strain [30, 32, 35,]. In the current study, P. multocida species were detected from the blood and nasal swabs of clinically sick camels. It was confirmed that the primer pair targeting KMT1 gene amplified $18.6 \%$ (19/102) of the total whole blood samples and $6.7 \%(2 / 30)$ of nasal swabs indicating that nasal carriage was not abundant. The study results confirms the findings obtained in other study that reported amplicon product of $460 \mathrm{bp}$ size supporting the application of PCR for rapid and specific amplification of $K M T 1$ gene for the detection of $P$. multocida [18, 19, 21, 30, 33]. Clarification of genes for capsule biosynthesis has made the development of Multiplex PCR for laboratory typing of P.multocida based on specific capsular gene sequences possible [31]. Multiplex PCR applied for capsular typing revealed that all positive $P$. multocida isolates were capsular group $\mathrm{E}$. This findings is in disagreement with earlier studies which reported that capsular group $B$ is the characteristic capsular group detected in camels [20,30,35] while another study done by Gluecks et al. (2017) reported capsular group $A$ and $D$ as the cause of pasteurellosis in camels. These finding demonstrate that it is not clear which capsular group is mainly responsible for pasteurellosis in camels. Furthermore the structure of capsular type B capsule remains unknown [32] thus its role as the causative agent for pasteurellosis in camels remain unclear and need further investigation. Blast search of the $P$. multocida isolates sequences matched with high similarity to accession number [LR134532.1] (Figure 4) and for capsular group E accession number [AF302466.1] (Figure 6). BLASTx search of $P$. multocida sequences for protein matched with high score of $98 \%$ to hydrolase family protein, Kmt1, outer membrane protein and 
alpha/beta hydrolase (Figure 5) and $100 \%$ to putative glycosyltransferase $E c b J$ for capsular group E (Figure 7) [29]. Upon alignment of the isolates sequences with ten (10) sequences retrieved from GenBank using BioEdit software version $7.2[15,16]$ revealed that the field strains had regions that were highly conserved. There were few regions with differences (Table 4). This indicated that the field strains had not mutated a lot in different camels. The Kenyan isolates clustered in different clades with isolates from other regions indicating that there was different $P$. multocida strain circulating in Marsabit and Turkana Counties in Kenya. In this study one Kenyan isolate [tur/nad/c2] was found to be $P$.multocida positive but in capsular typing it did not produce band, these are referred to be untypable isolates of $P$. multocida which are sometimes encountered especially when the organism is in the acapsular state [10]. Only capsular group E was detected, other capsular groups A, B, D and F were not detected. Blast search of capsular group E sequences matched with accession number [AF302466] for $P$. multocida P1234 region 2 capsule biosynthesis gene cluster (Figure 6). There is definite relationships between $P$. multocida capsular group, specified diseases and species which is also influenced by geographical distribution of capsular groups [13]. There has been deviation from this relationships which have been exhibited in recent years [13]. Examples is the pig pneumonia caused by capsular type $D$ but initially was linked to capsular group A. There is a likelihood of one capsular group to transmit infection to different species and cause different disease manifestation [10]. Example of capsular group A that causes fowl cholera, calf pneumonia, pneumonia in pigs and upper respiratory tract infections in dogs and cats [10]. Pasteurellosis has been associated with capsular group E in Africa [10]. The variation rate of $P$. multocida in camel may result from different sample size, method of sample collection and differences amongst geographical areas of Marsabit and Turkana. Close herding, overwork, limited food supply, and wet climatic conditions are stresses that seem to speed the spread of the infection thus there is an urgent need to identify the source of respiratory diseases in camels to organize better control strategies. In this study $21 / 132$ Kenyan isolates were found to be $P$.multocida and in capsular typing they were found to be capsular type E. Multiplex PCR provided a quick replacement to available phenotypic tests for the identification of capsulated $P$. multocida because it allows the concomitant, quick detection of genes and capsular typing $[10,13]$.

\section{Conclusion}

The study confirm that the camels were infected by $p$. multocida of capsular type $E$ in Marsabit and Turkana Counties of Kenya. Farmers should give camels dietary nutrition, properly treat and vaccinate camels, minimize close herding of camels especially in wet condition to slow the fast spreading of pasteurellosis. This study serves as the basis for further research on pasteurellosis, P. multocida genetic diversity and Molecular epidemiology.

\section{Abbreviations}

DNA

LPS deoxyribonucleic acid

lipopolysaccharide 
PCR

$\mathrm{MgCl} 囚$

dNTPs

NCBI

BLAST

MEGA polymerase chain reaction

Magnesium chloride

deoxyribonucleotidestriphosphates

National centre for biotechnology information

Basic local alignment search tool

Molecular evolutionary genetic analysis

\section{Declarations}

\section{Ethics approval and consent to participate}

The Director of Veterinary Services was informed about the study and gave approval for the use of the blood and nasal swabs sample stored at Central Veterinary Laboratories, Kabete. All the procedures were carried out according to ethical guidelines for the use of animal samples permitted by Directorate of Veterinary Services Kenya (Permit number MOALF/SDL/DVS/RES/GEN/018).

The License to Conduct the Research was sought from National Commission for Science, Technology and Innovation (Nacosti) License No: Nacosti/P/19/1288.

\section{Consent for publication}

Not Applicable

\section{Availability of data and materials}

All data generated or analysed during the study are included in this published article and its supplementary information files.

\section{Competing interests}

The authors declare that they have no competing interests

\section{Funding}

Materials, reagents and samples were provided by Molecular Laboratory, Central Veterinary Laboratories directorate of Veterinary Services Kabete Kenya. Primers provided by International Atomic Energy Agency (IAEA) Seibersdorf Laboratory, Vienna Austria.

\section{Authors' contributions}


JKK and GIO developed the concept and study design, JKK retrieved samples from archive. JKK performed sample testing. GIO and GOA interpreted the data, gave guidance on how to present the results. all the author's read and approved the final manuscript.

\section{Acknowledgements}

I extend my sincere thanks to the Directorate of Veterinary services for approving the use the samples to carry out my study. Special thanks to International Atomic Energy Agency (IAEA) through William Dundon Animal production and Health laboratory joint FAO/ IAEA Laboratories, Seibersdorf, Austria for assisting with primers and sequencing services. I also extend my gratitude to Mr. Stephen G. Gacheru Principal Laboratory technologist Directorate of Veterinary Services, Central Veterinary Laboratory, Kabete Molecular Laboratory for guiding me and giving necessary advice.

\section{References}

1. Abbas AM, Abd El-Moaty DAM, Zaki ESA, El-Sergany EF, El-Sebay NA, Fadl HA, Samy AA. Use of molecular biology tools for rapid identification and characterization of Pasteurella Veterinary world open access and peer reviewed journal. 2018; 7: 1006-1014.

2. Abdeltawab AAA, Fatma I. El -Hofy, Attia Al-Jeddawy, Ebtehal Abo-Hamdah, Pasteurella multocida in camels: incidence, capsular and virulence genes characterization, benha veterinary medical journal. $2016 ; 2: 171-175$.

3. Ahmed S. Molecular Characterization of Pasteurella multocida Isolated from Rabbit in M.S. AbdelSalam, S.S. Hafez and W. Nemr, Egypt. American Journal of Biochemistry and Molecular Biology. 2016; 6:53-59.

4. Aski HS, Tabatabaei M. Molecular characterization of Pasteurella multocida isolates obtained from poultry, ruminant, cats and dogs using RAPD and REP-PCR analysis. Molecular Biology Research Communication. 2016; 3: 123-132.

5. Bhimani MP, Roy A, Bhander BBi, Mathakiya RA. Isolation identification and molecular characterization of Pasteurella multocida isolates obtained from emu (Dromaius novaehollandiae) in Gujarat state, India. Vet. Arhiv. 2014; 84: 411-419.

6. Brenda AW, Mengfei Ho. Pasteurella multocida, from Zoonosis to Cellular Microbiology, Clinical Microbiology Reviews. 2013; 3: 631-655.

7. Kenya population and housing census. 2019. https://www.knbs.or.ke/?p=5621. Accessed $17^{\text {th }}$ March 2021.

8. Centre for Economic Governance. https://cegkenya.org/kenya-taps-innovative-digital-mapping-toenhance-public-participation/. Accessed 1 October 2021 
9. Treves DS. Review of Three DNA Analysis Applications for Use in the Microbiology or Genetics Classroom. Journal of Microbiology and Biology education. 2010; 2: 186-187.

10. Dziva F, Mohan K, Pawandiwa A. Capsular serogroups of Pasteurella multocida isolated from animals in Zimbabwe, Onderstepoort Journal of Veterinary Research. 2000; 67:225-228

11. Elsayed MSAE, Eldsouky SM, Roshdy T, Said L, Thabet N, Alla T, Mohammed AB., Nasr GM, Basiouny MSM, AkI BA. Virulence Determinants and Antimicrobial Profiles of Pasteurella multocida Isolated from Cattle and Humans in Egypt. Antibiotics. 2021; 10: 480.

12. Food and Agriculture Organisation. Agriculture and consumer protection Department, EMPRESAnimal Health 2019. http://www.fao.org/ag/againfo/programmes/en/empres/disease_haemo.asp. Accessed 27 September 2021.

13. Furian TQI, Borges KAl, Pilatti RMI, Almeida Cl, Nascimento VP dol, Salle CTPI, Moraes HL de SI . Identification of the Capsule Type of Pasteurella Multocida Isolates from Cases of Fowl Cholera by Multiplex PCR and Comparison with Phenotypic Methods, Brazilian Journal of Poultry Science. 2014; 2: 31-36.

14. Gluecks IV, Bethe A, Younan M, Ewers C. Molecular study on Pasteurella multocida and Mannheimia granulomatis from Kenyan Camels (Camelus dromedarius). BioMedCent ral veterinary research, open access. 2017; DOI 10.1186/s12917-017-1189.

15. Hall TA. A user friendly biological sequence alignment editor and analysis program for windows 95/98/NT, oxford University press, nucleic acid symposium series No. 41. 1999; 95-98.

16. Hall TA, biosciences I, Carlsbad Ca. an important software for molecular biology, GERF Bulletin of Biosciences. 2011; 1:60-61.

17. pureLink ${ }^{T m}$ Genomic DNA kits for purification of genomic DNA Catalog nos. K1820-01, K1820-02, K1821-04.2007. https://www.citeab.com/kits/7604402-k1820-01-purelink-genomic-dna-mini-kit. Accessed 1 October 2021.

18. Jabbari AR, Banihashemi SR, Valadan M, Tadayon K. Molecular identification and capsular typing of Pasteurella multocida isolates from sheep pneumonia in Iran. International Journal of Molecular and Clinical Microbiology. 2014; 2: 417-423

19. Jakeen K. El-Jakee, Samah SA, Soumaya A El-Shafii, Ashgan MH, Abdullah A Al-Arfaj, Moussa I M. Comparative studies for serodiagnosis of haemorrhagic septicaemia in cattle sera, Saudi Journal of Biological Sciences. 2015; 23: 48-53.

20. Kebede F, Gelaye E. studies on major respiratory diseases of camels (Camelus dromedarius) in north eastern Ethiopia. Afr. J Microbiol. 2010; 4: 1560-1564. 
21. Khalid S Al-Maary, Turki MD, Ayman SM, Ashgan MH, Hussein MG, Saleh AK, Moussa IM. Molecular characterization of the capsular antigens of Pasteurella multocida isolates using multiplex PCR. Saudi Journal of Biological Sciences. 2016; 24: 367-370.

22. Khan FM. Field epidemiology of an outbreak of hemorrhagic septicemia in dromedary Population of greater Cholistan desert (Pakistan), Pak Vet J. 2012; 1: 31-34.

23. Kumar S, Stecher G, Li M, Knyaz C, Tamura MEGA X Molecular Evolutionary Genetics Analysis across Computing Platforms, Molecular Biology and Evolution. 2018; 6: 1547-1549.

24. Kurnaz IA. Techniques in genetic engineering. $1^{\text {st }}$ Edited by Taylor and Francis group, LLC, U.S 2015; 257-265, 265-267

25. Kearse M, Moir R, Wilson A, Havas SS, Cheung M, Sturrock S, Buxton S, Cooper A, Markowitz S, Duran C, Thierer T, Ashton B, Meintjes P, Drummond A . Geneious Basic: An integrated and extendable desktop software platform for the organization and analysis of sequence data Bioinformatics. 2012; 15: $1647-1649$.

26. Manual of Diagnostic Tests and Vaccines for Terrestrial Animals vol. 1, 2, 3. 2012. . www.oie.int/fileadmin/Home/eng/Animal Health in the World/docs/pdf/Disease cards/HAEMORRHAGIC_SEPTIC.,http://www.oie.int/standard-setting/terrestrial-manual/. Accessed 20 February 2020

27. J. Haemorrhagic Septicaemia Diseases Caused by Bacteria; Jibachha's Applied Preventive medicine. 2011. https://www.scribd.com/document/324602026/HAEMORRHAGIC-SEPTICAEMIA-HS. Accessed 15 January 2021

28. Smith E, Miller E, Aguayo JM, Figueroa CF. Nezworski J, Studniski M. Genomic diversity and molecular epidemiology of Pasteurella multocida. PLoS ONE. 2021; 4: e0249138.

29. Stephen FA, Thomas LM, Alejandro AS, Jinghui Z, Zheng , Miller W, Lipman DJ. Gapped BLAST and PSI-BLAST: a new generation of protein database search programs", Nucleic Acids. 1997; 25:33893402.

30. Tahamtan Y, Amrabadi O, Shahryari R. Identification of Pasteurella multocida and molecular diagnosis of haemorrhagic septicaemia in Iranian camels, Revue Méd. Vét. 2016; 6: 126-132.

31. Teleb A, Hassan GM, Yaseein A, Fiky ZE. Conventional and molecular differentiation between capsular types of Pasteurella multocida isolated from various animal hosts. Journal of Advanced Laboratory Research in Biology. 2019; 1: 1-7.

32. Townsend KM, Frost AJ, Lee CW, Papadimitriou JM, Dawkins HJS. Development of PCR assays for species- and type-specific identification of Pasteurella multocida isolates, Journal of Clinical 
Microbiology.1998; 36: 1096-1100.

33. Townsend KM, Boyce JD, Chung JY, Frost AJ, Adler B. Genetic organization of Pasteurella multocida cap loci and development of a multiplex capsular PCR typing system. Journal of Clinical Microbiology. 2001; 39: 924-929.

34. Treves D. S. Review of Three DNA Analysis Applications for Use in the Microbiology or Genetics Classroom, journal of Microbiology and Biology education. 2010; 2: 186-187.

35. Vidhya M, Chandran NDJ, Paul WM, Raj GD. Molecular identification of serogroups of Pasteurella multocida isolated from sheep by capsular PCR typing, Tamilnadu J. Vet. Anim. Sci. 2007; 3: 140143.

\section{Figures}

Panel A

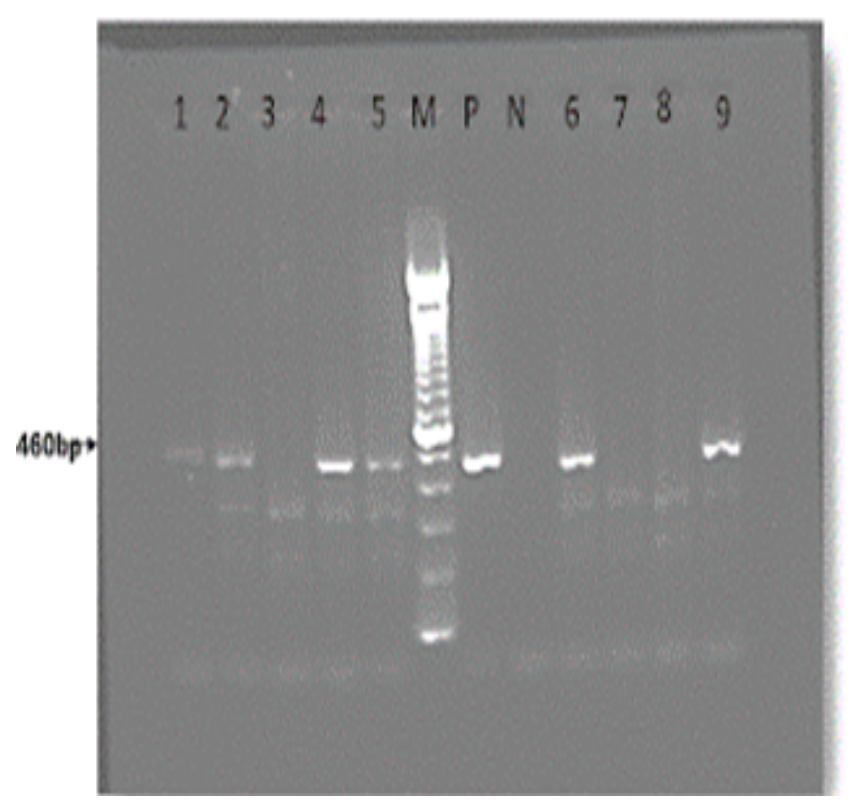

Panel $B$

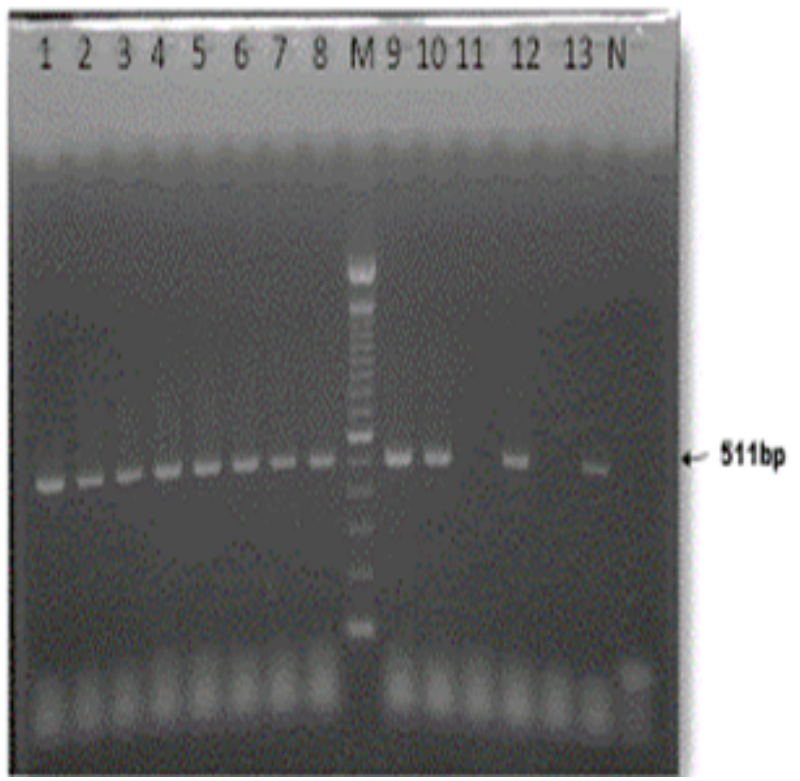

\section{Figure 1}

Conventional PCR amplification of P. multocida KMT1 gene (Panel A) and capsular type E ecbJ gene (Panel B). The PCR products were analysed by gel electrophoresis on a $1.5 \%$ agarose gel and stained with gel red. Panel A: 1, 2, 4, 5, 6, 9 are positive samples.3, 7, 8 are negative samples. M-molecular size marker100bp, p-positive control, $\mathrm{N}$ - negative control. Panel B: 1, 2, 3, 4, 5, 6, 7, 8, 9, 10, 12, 13 are positive samples.11 negative sample. M-molecular size marker100bp, $\mathrm{N}$ - negative control. 460bp size fragment specific for pasteurella multocida and $511 \mathrm{bp}$ size fragments specific for capsular type E ecbJ gene. Arrow point at the position of the amplicons. 


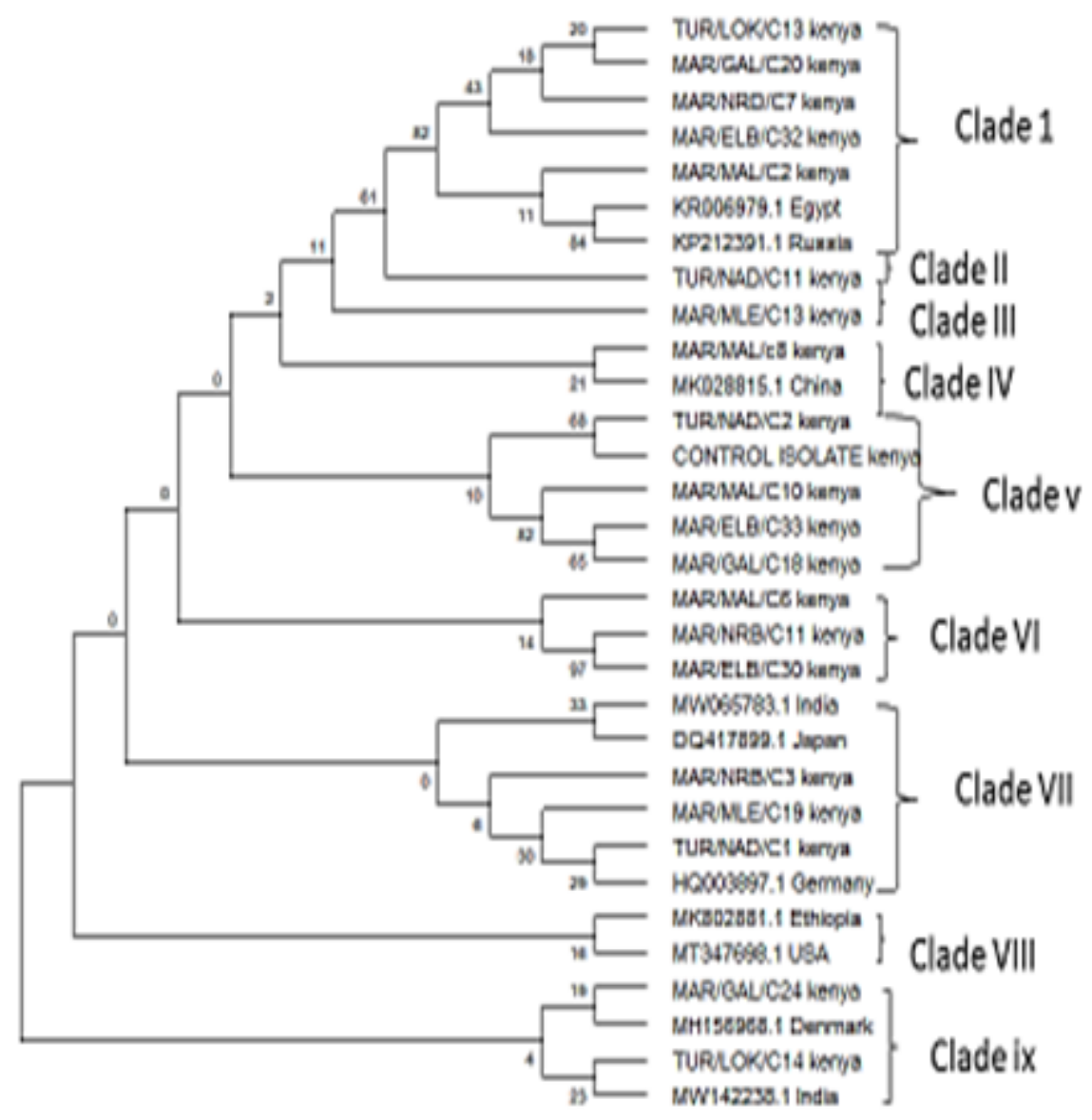

Figure 2

Phylogenetic tree based on the kmt 1 fragment of $\mathrm{p}$. multocida isolated from camels in Marsabit, Turkana and other regions of the world. The phylogenetic tree constructed by maximum likelihood using MEGA X software. Phylogeny tested with 1000 bootstrap replications. 


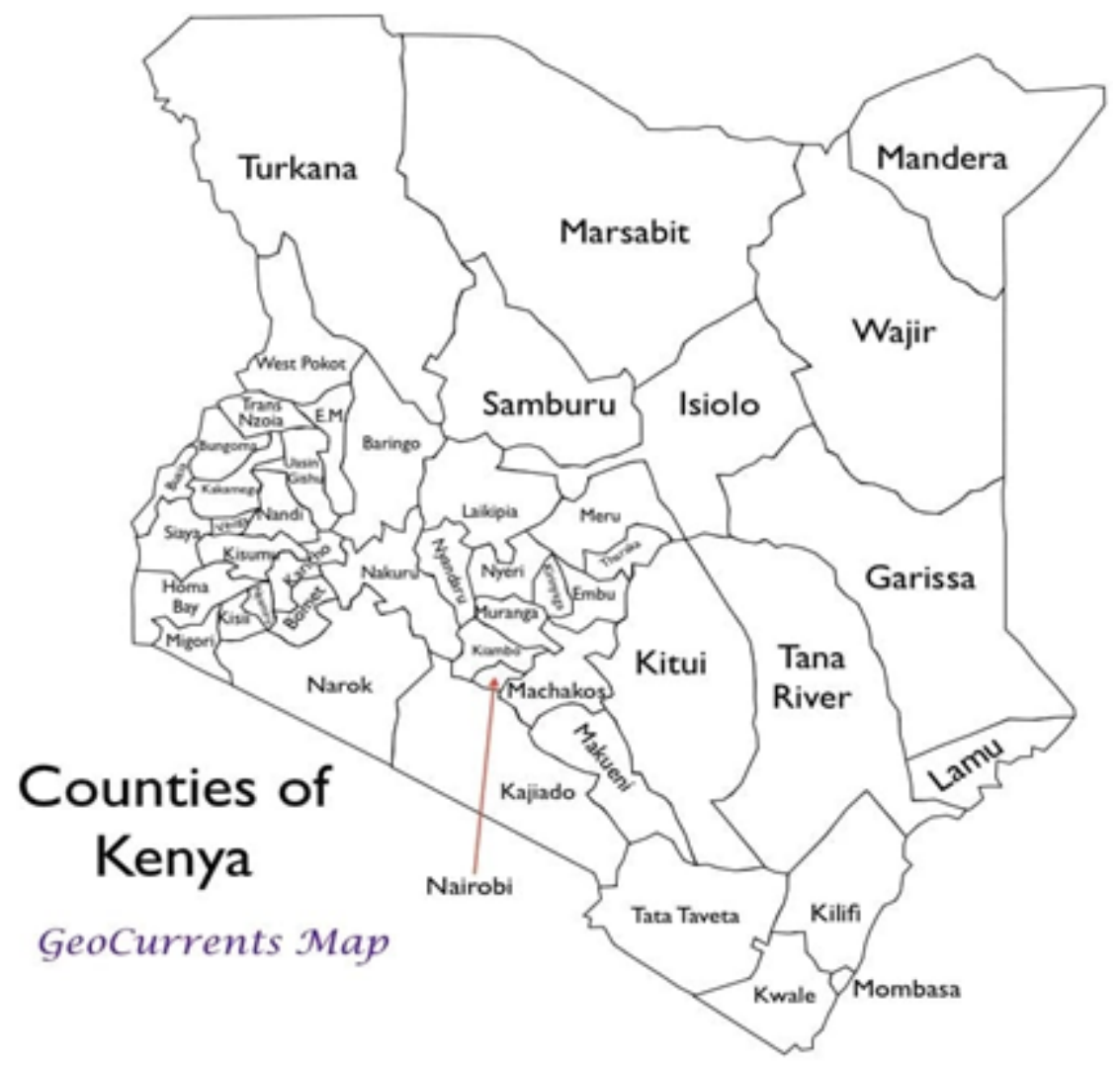

Figure 3

Location of Marsabit and Turkana Counties in Kenya [8] 
select all osequences selected

$$
\text { Description }
$$

Pasteurel a multocida strain NCTC10323 genome assembly. chromosome: 1

Pasteurela multocida strain 375.A115 chromosome

Pasteurela multocida strain Razi_Pm0001. complete genome

Pasteurella multocida strain Jhakhrana hydrolase family, cortein (knt) gene, gattial cods

Pasteurela multocida strain NCTC10382 genome assembly. chromosome: 1

Pasteurela multocida strain FDAARGOS_218 chromosome. condete genome

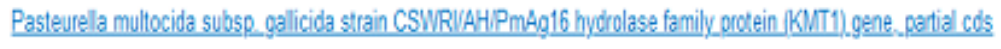

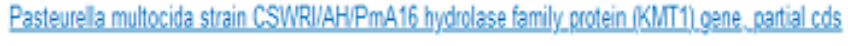

Pasteurela multocida OH1905. complete genome
GenBank Graphics Distance tree of results

\begin{tabular}{|c|c|c|c|c|c|}
\hline $\begin{array}{l}\text { Max } \\
\text { Score }\end{array}$ & $\begin{array}{l}\text { Total } \\
\text { Score }\end{array}$ & $\begin{array}{l}\text { Query } \\
\text { Cover }\end{array}$ & $\begin{array}{c}E \\
\text { value }\end{array}$ & $\begin{array}{l}\text { Per. } \\
\text { Ident }\end{array}$ & Accession \\
\hline & 809 & $98 \%$ & 0.0 & $99.11 \%$ & 4532.1 \\
\hline & 809 & $98 \%$ & 0.0 & $99.11 \%$ & \\
\hline & 809 & $98 \%$ & 0.0 & $99.11 \%$ & 9961. \\
\hline & 804 & $98 \%$ & 0.0 & $98.89 \%$ & 8143.1 \\
\hline & 798 & $98 \%$ & 0.0 & $98.67 \%$ & \\
\hline & 798 & $98 \%$ & 0.0 & $98.67 \%$ & \\
\hline & 798 & $98 \%$ & 0.0 & $98.67 \%$ & \\
\hline & 798 & $98 \%$ & 0.0 & $98.67 \%$ & \\
\hline & 798 & $98 \%$ & 0.0 & 98.67 & \\
\hline
\end{tabular}

B

\section{Pasteurella multocida strain NCTC10323 genome assembly, chromosome: 1}

Sequence ID: LR134532.1 Length: 2330363 Number of Matches: 1

Range 1: 1687195 to 1687645 GenBank Graphics

7 Next Match $\Delta$ Previous Match

\begin{tabular}{|c|c|c|c|c|c|c|}
\hline \multicolumn{2}{|c|}{$\begin{array}{l}\text { Score } \\
809 \text { bits(438) }\end{array}$} & $\begin{array}{l}\text { Expect } \\
0.0\end{array}$ & $\begin{array}{l}\text { Identities } \\
447 / 451(99 \%)\end{array}$ & $\begin{array}{l}\text { Gaps } \\
1 / 451(0 \%)\end{array}$ & $\begin{array}{l}\text { Strand } \\
\text { Plus/Plus }\end{array}$ & \\
\hline Query & 7 & \multicolumn{4}{|c|}{$\begin{array}{l}\text { AAACG-ACTCGCCCTTTTGTTCATTTGGACTGACACGATTAAACCGTGAACACGAA } \\
|||||||||||||||||||||||||||||||||||||||||||||||||||||||||||||||||||||| l \mid\end{array}$} & 65 \\
\hline Sbjet & 1687195 & \multicolumn{4}{|c|}{ AAACGAACTCGCCACTTTTTGTTTCATTTGGACTGACACGATTAAACCGTTGAACACGAA } & 1687254 \\
\hline Query & 66 & \multicolumn{4}{|c|}{$\begin{array}{l}\text { GAAAAAGACCAAAATAGGTAACCAATACACGATAAATAAATTAAACCGCTCTGTCGTTAA } \\
||||||||||||||||||||||||||||||||||||||||||||||||||||||||||\end{array}$} & 125 \\
\hline sbjet & 1687255 & \multicolumn{4}{|c|}{ GAAAAAGACCAAAATAGGTAACCAATACACGATAAATAAATTAAACCGCTCTGTCGTTAA } & 1687314 \\
\hline Query & 126 & \multicolumn{4}{|c|}{ 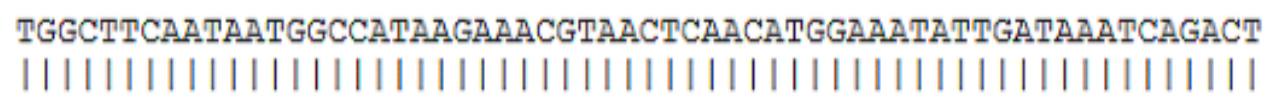 } & 185 \\
\hline sbjet & 1687315 & \multicolumn{4}{|c|}{ TGGCTTCAATAATGGCCATAAGAAACGTAACTCAACATGGAAATATTGATAAATCAGACT } & 1687374 \\
\hline Query & 186 & \multirow{2}{*}{\multicolumn{4}{|c|}{ 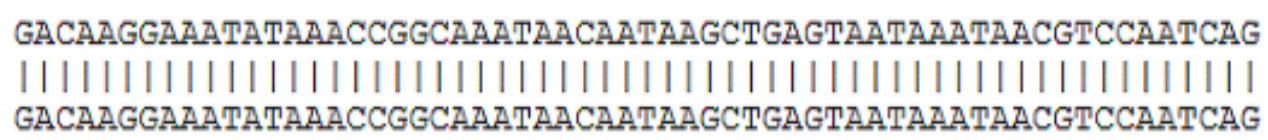 }} & 245 \\
\hline Sbjet & 1687375 & & & & & 1687434 \\
\hline
\end{tabular}

\section{Figure 4}

Blastn description of sequences producing significant alignments and nucleotide base pairing. 
$\mathbf{A}$

Sequences producing significant alignments

Download $\vee$ Manage Columns $\vee$ Show $100 \vee 0$

select all 98 sequences selected

GenPept Graphics

Description

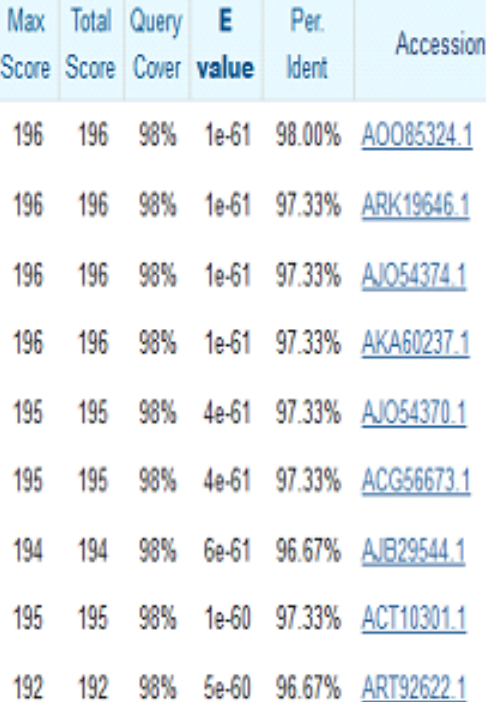

B $\square$ hydrolase family crotein [Pasteurella mutocida]

\section{hydrolase family protein, partial [Pasteurella multocida]}

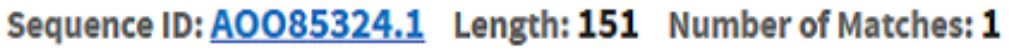

Range 1: 1 to 150 GenPept Graphics

$\underline{\text { Next Match }}$ A Previous Match

\begin{tabular}{|c|c|c|c|c|}
\hline \multicolumn{2}{|c|}{$\begin{array}{l}\text { Score } \\
196 \text { bits(499) }\end{array}$} & $\begin{array}{ll}\text { Expect Method } & \text { Identities } \\
1 \mathrm{e}-61 \text { Compositional matrix adjust. } & 147 / 150(98 \%)\end{array}$ & $\begin{array}{ll}\text { Positives } & \text { Gaps } \\
147 / 150(98 \%) & 0 / 150(0 \%)\end{array}$ & $\begin{array}{l}\text { Frame } \\
-2\end{array}$ \\
\hline Query & 455 & $\begin{array}{l}\text { PLITQWGGANEPIAARLSFMPLEMGNGiilwlvvsglvgs] } \\
\text { PL TQWGGANEPIAARLSFMPLEMGNGIILWLVVSGLVGSI }\end{array}$ & $\begin{array}{l}\text { IfgIWQRRAQFCWAEFGVL } \\
\text { LFGLWQRRAQFCWAEFGVL }\end{array}$ & 276 \\
\hline Sbjet & 1 & PLFTQWGGANEPIAARLSFMPLEMGNGIILWLVVSGLVGSI & IFGLWQRKAQFCWAEFGVI & 60 \\
\hline Query & 275 & $\begin{array}{l}\text { SQSASLTTAQIigrYll1slllfaglyflvSLIYQYFHVEI } \\
\text { SQSASLTTAQLIGRYLLSILLFAGLYFLVSLIYQYFHVEI }\end{array}$ & $\begin{array}{l}\text { RFLWPLLRPLTTERFNLFI } \\
\text { RFLWPLIRPLTTERFNLFI }\end{array}$ & 96 \\
\hline sbjet & 61 & SQSASLTTAQLIGRYLILSLLLFAGLYFLVSLIYQYFHVEI & RFLWPLLRPLTTERFNLFI & 120 \\
\hline Query & 95 & $\begin{array}{l}\text { VYWLPILVFFFVFNGLIVSVQMRQRGASRF } \\
\text { VYWLPILVFFFVFNGLIVSVQMRQR AS F }\end{array}$ & & \\
\hline sbjet & 121 & VYWLPILVFFFVFNGLIVSVQMRQRVASSF & & \\
\hline
\end{tabular}

\section{Figure 5}

Blastx description alignment showing sequences producing significant alignments and translated nucleotide to protein 
A

Sequences producing significant alignments

Download $\vee$ Manage Columns $\vee$ Show $100 \vee 0$

selectall 1 sequences selected

GenBank Graphics Distance tree of results

Description

Max Total Query E Per.

Score Score Cover value Werit

Accession

$\checkmark$ Pasteurella multocida P1234 region 2 capsule biosunthesis gene custer, petial sequence

$948 \quad 948 \quad 100 \% \quad 0.0 \quad 100.00 \% \quad$ AF 302466.1

I Pasteurella multocida P1234 region 2 capsule biosynthesis gene cluster, partial sequence Sequence ID: AF302466.1 Length: 11745 Number of Matches: 1

Range 1: 4389 to 4901 GenBank Graphics

$\nabla$ Next Match $\Delta$ Previous Match

\begin{tabular}{|c|c|c|c|c|c|c|}
\hline \multicolumn{2}{|c|}{$\begin{array}{l}\text { Score } \\
948 \text { bits(513) }\end{array}$} & $\begin{array}{l}\text { Expect } \\
0.0\end{array}$ & $\begin{array}{l}\text { Identities } \\
513 / 513(100 \%)\end{array}$ & $\begin{array}{l}\text { Gaps } \\
0 / 513(0 \%)\end{array}$ & $\begin{array}{l}\text { Strand } \\
\text { Plus/Plus }\end{array}$ & \multirow[b]{2}{*}{60} \\
\hline Query & 1 & \multicolumn{4}{|c|}{ 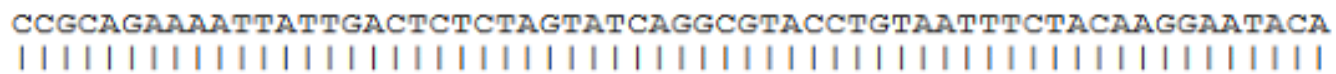 } & \\
\hline sbjet & 4389 & \multicolumn{4}{|c|}{ CCGCAGAAAATTATTGACTCTCTAGTATCAGGCGTACCTGTAATTTCTACAAGGAATACA } & 444 \\
\hline Query & 61 & \multicolumn{4}{|c|}{ 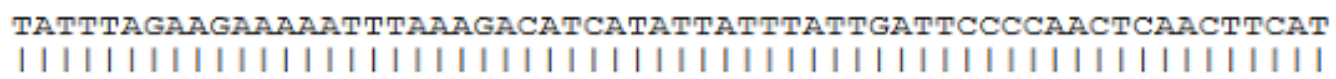 } & 120 \\
\hline sbjet & 4449 & \multicolumn{4}{|c|}{ TATTTAGAAGAАAАATTTAAAGACATCATATTATTTATTGATTCCCCAACTCAACTTCAT } & 450 \\
\hline Query & 121 & \multicolumn{4}{|c|}{ 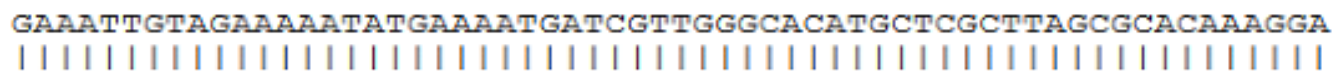 } & 180 \\
\hline sbjct & 4509 & \multicolumn{4}{|c|}{ GAAATTGTAGAAAAATATGAAAATGATCGTTGGGCACATGCTCGCTTAGCGCACAAAGGA } & 4568 \\
\hline Query & 181 & \multirow{2}{*}{\multicolumn{4}{|c|}{$\begin{array}{l}\text { TATCGATTTGTAATGAATAATTTTCCACACATAGTCTCAAAGCTAACTTACAAAGAGAA } \\
\text { | | | | | | | | | | | | | | | | | | | | | | | | | | | | | | | | | | | | | | | | | | | | | | | | | | | | | | | | | | | | } \\
\text { TATCGATTTGTAATGAATAATTTTTCCACACATAGTCTCAAAGCTAACTTACAAAGAGAA }\end{array}$}} & 240 \\
\hline sbjct & 4569 & & & & & 462 \\
\hline
\end{tabular}

\section{Figure 6}

Blastn description of sequences producing significant alignments and nucleotide base pairing for capsular EcbJ gene. 
D selectall osequencesselected

\section{Description}

Dutative oycosytitansferase EcbJ [Pasteurella muliocida]

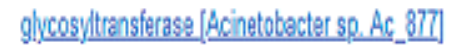

[- gycosy/transferase [Acinetobacter equ]]

- glycosyitransferase (Dannheimia haemoldica)

Lyoothetical protein C4091_00325 [Nannheimia haemolyica]

ghccosyttransferase [Nannheimia haemoldica]

MULTISPECIES: dycosytiransterase [unclassified Alcaligenes]
GenPept Graphics

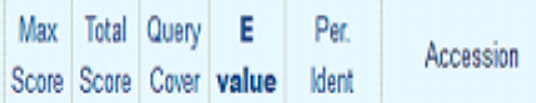

$348 \quad 348 \quad 100 \% \quad 50-114 \quad 100.00 \%$ AAK17912.1

$\begin{array}{lllllll}127 & 127 & 9996 & 20.30 & 40.35 \% & \text { WP } & 152873934.1\end{array}$

$122 \quad 122 \quad 9996 \quad 6 e .29 \quad 40.12 \%$ WP 054580589.1

$104 \quad 104 \quad 98 \% \quad 10.22 \quad 34.52 \% \quad$ WP 051888062.1

$103 \quad 103 \quad 98 \% \quad 30.22 \quad 34.52 \% \quad$ AWW 65499.1

$103 \quad 103 \quad 98 \% \quad 38.22 \quad 34.52 \% \quad$ WP

$\begin{array}{llllll}102 & 102 & 999 & 70.22 & 33.92 \% & \text { WP } \\ 0.099453505 .1\end{array}$

\section{B putative glycosyltransferase EcbJ [Pasteurella multocida]}

\section{Sequence ID: AAK17912.1 Length: 705 Number of Matches: 1}

Range 1: 382 to 552 GenPept Graphics

$\nabla$ Next Match $\Delta$ Previous Match

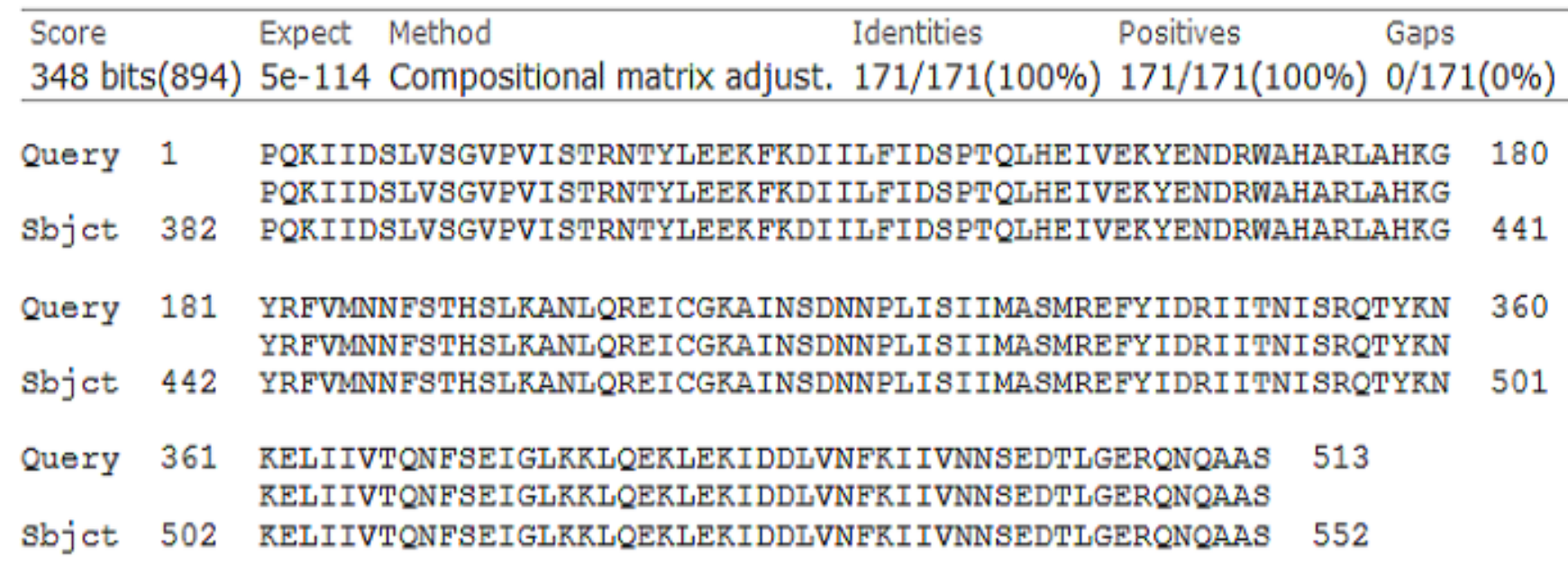

\section{Figure 7}

Blastx alignment showing description of sequences producing significant alignments and translated nucleotide to protein for Ecbj gene. 


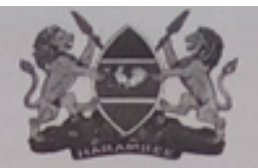

REPUBLIC OF KENYA

\section{MINISTRY OF AGRICULTURE, LIVESTOCK AND FISHERIES \\ STATE DEPARTMENT OF LIVESTOCK \\ Office of the Director of Veterinary Services}

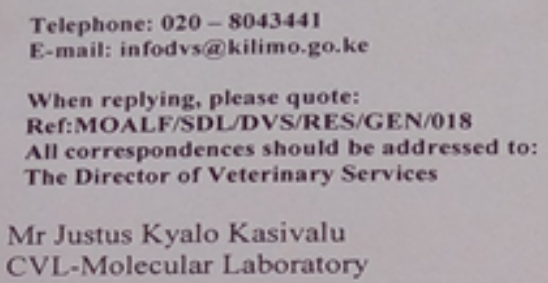

Mr Justus Kyalo Kasivalu

CVL-Molecular Laboratory

\section{Dear Mr Kasivalu,}

\section{Request to use Camel samples for Masters Project}

Your unreferenced letter dated $29^{\text {th }}$ January 2019 on the above subject refers.

You have indicated that you are pursuing a Master's degree in Biotechnology at Kenyatta University where you plan to study Camel Pasteurellosis, which is a zoonotic disease. I further note that your study will be offered on a part time basis.

It is important that you indicate the title of your project and the specific objectives of your study. From those objectives, one can visualize the scope of Camel Pasteurellosis data required as well as number and type of laboratory samples expected.

It is advisable that you regularize your training need with the Departmental Training Committee.

Your request to use camel samples under CVL custody is hereby granted.

The results of the study should be shared with the Directorate of Veterinary Services through our research liaison office.

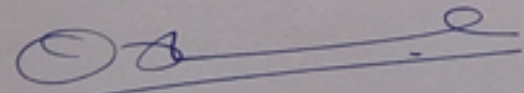

Dr Obadiah N Njagi, PhD

Director of Veterinary Services

\section{Figure 8}

Request to use camel samples for master's project

\section{Supplementary Files}

This is a list of supplementary files associated with this preprint. Click to download.

- Table1.docx

- Table2.docx 
- Table3.docx

- Table4.docx

- Table5.docx

- Table6.docx

- Table7.docx 